\title{
THE POLLUTER PAYS PRINCIPLE AND THE REMEDIATION OF LAND
}

\author{
Emma Lees*
}

Keywords: contamination, environmental liability, polluter pays principle

\section{Abstract}

The Environmental Liability Directive attempts to provide a harmonising framework for liability for environmental damage within the European Union on the basis of the polluter pays principle. This article considers legislation in place in the Member States which sit alongside provisions based on the ELD. It shows that such regimes rely on different models for liability, which require, in turn, fundamentally different understandings as to how the polluter pays principle can work as a principle of liability. It considers provisions in place in Denmark, the United Kingdom, the Walloon Region, the Netherlands, and Germany. The differences between these systems are not differences of degree, nor are they mere technicalities, rather they represent a significant challenge not only to the goals of the ELD, but to the principles underpinning it. By undertaking a comparative analysis of these systems, it becomes clear not only that the ELD sits uncomfortably with these "parallel" provisions, but also that this discomfort is not only one of overlapping and complex legislative provisions, but rather one of underlying justification for liability.

'The purpose of the Environmental Liability Directive ("ELD") is to establish a framework of environmental liability, based on the 'polluter-pays' principle, to prevent and remedy environmental damage' (European Commission, 2006, p. 1; A. Waite, 2006, p. 67). This goal is threatened by the variation in Member State liability for remediation of land which sits alongside the ELD in the Member States. When the legislation in Member States relating to contaminated land is examined, it becomes clear that the Member States prefer to extend liability beyond the liability of the polluter. This is not merely a difference of degree with the ELD, nor can it simply be dismissed as differing liability for different problems. Rather, it represents a profound conflict in understanding as to the operation of the polluter pays principle. A comparative study of the legal mechanisms in place across Europe demonstrates different models liability for contaminated land, and shows that the intuitive appeal of the polluter pays principle, once translated into law, becomes malleable, contested, and conflicted. This raises a significant further question: wherein lies the appeal of the polluter pays principle, and does the existence of supplementary legislation undermine that appeal? If so, perhaps alternative justifications, including obligations of stewardship, are required to explain liability in relation to damage to land.

This article considers the network of regulation which extends across the Member States concerning remediation of contaminated land, in order to assess whether that network is one which can coherently sit alongside the ELD and its invocation (and interpretation of) the polluter pays principle. It will be shown that across Europe there is significant variation in models for liability for contaminated land. This has inevitable results for the harmony of the ensuing system, and for the relationship between national regimes for the remediation of contaminated land and the ELD. The consequences of this for the success of the both the polluter pays principle in general (as a principle of both liability and economics), and of the ELD, are significant. In essence, the Union interpretation of the polluter pays principle is not shared by the Member States. This is not because their laws are explicitly or implicitly based upon different models of the polluter pays principle as such. Rather, the conflict emerges because the very existence of the different models for liability results in conflict with how the ELD, and the ECJ in its consideration of the polluter pays principle, understand how that

\footnotetext{
* University Lecturer in Environmental and Property Law, Department of Land Economy, University of Cambridge.
} 
principle works. This undermines the harmonisation of the polluter pays principle as a principle of Union law, and the harmonisation of environmental liability in relation to contaminated land of course, but it also does something more fundamental than that. This divergence threatens to undermine the coherence in reliance on the polluter pays principle by the institutions of the EU.

\section{A Patchwork System and Incoherence in Justification}

It has recently been noted in the implementation report by the DG for the Environment of the European Commission (Bio Intelligence Service, 2013) that the implementation of the ELD is patchwork (the full report emerging from this process is still to be completed (European Commission, 2014)). There is significant variation across the Member States in relation not only to the definition of operator (a variation explicitly permitted by the Directive itself, article 2(6)), but also in relation to the existence and development of a register of damage, publication of data in relation to environmental damage, the degree of access to such data, and the repeal of overlapping legislation (Stephens Bolton LLP, 2013, p. 6).

A number of different factors are cited in the Commission report to explain the variation between Member States. One primary factor relied upon in this report however is 'the state of development of environmental law in individual Member States' (Stephens Bolton LLP, 2013 , 6). Indeed, when the transposition of the ELD into the relevant legal system is examined, it becomes clear that, for the most part, existing legislation is left intact, with the ELD superimposed onto that system, leaving sometimes more stringent, and importantly, very different legislation in place. The provisions of the ELD then tend to take only a residual role (albeit that in some States the ELD will take precedence, e.g. Denmark ${ }^{1}$ ). Thus, the state of development of environmental law in the particular legal system has necessary consequences on the overall system of liability for contaminated land. More profoundly however, it is argued that the state of development is a symptom, rather than a cause, of different approaches to environmental justice present in the Member States. This more profound variation is one which is not 'papered-over' by the harmonising attempt of the ELD. It is the purpose of this paper to explore one area of this more profound variation, in the understanding of the polluter pays principle as a principle justifying liability.

It is acknowledged that some variation is in fact part of the design of the ELD, and of the compromise in its drafting (de Smedt, 2009). There are provisions of the Directive itself which are optional (article 16, see L. Bergkamp and A. van Bergeijk, 2013). It is suggested however the variation goes deeper than this, reflecting different understandings of the polluter pays principle; a principle often invoked, but rarely analysed by those utilising it as a foundation for regulation (de Sadeleer, 2006, p. 101). There is academic analysis of this principle, not least by de Sadeleer (de Sadeleer, 2005, p. 21; de Sadeleer, 2006). This analysis highlights that the principle can only be understood by unpacking what is meant by polluter; and what exactly they should be required to pay for (the cost of the damage, the cost of repair, or more broadly, the cost to society of the damage having taken place) (de Sadeleer, 2006, p. 94). It is suggested here that there is in fact a third variable factor in understanding the principle: whether the principle requires that only the polluter pay (this is the interpretation adopted by the ELD itself), or whether the principle is merely one amongst many potential justifications for imposing liability. It is suggested that this difference is not one of degree, it is a fundamental disagreement as to the type of principle that this principle is.

Given this, any legislation which exists in Member States requiring that someone other than a polluter pay is not merely broader, or stricter (article 16), than legislation which does not, but rather, fundamentally opposed. A single piece of legislation cannot coherently represent both interpretations of this principle and any ambiguity as to which approach has been taken by a

\footnotetext{
${ }^{1}$ Contaminated Soil Act, Chapter 4a.
} 
Member State can thus produce incoherence when placed alongside the provisions of the ELD. Whilst inconsistency might per se be considered insignificant in the context of harmonisation, incoherence, or at least profound disagreement as to the very justification for liability in different parts of the same regime, poses significant problems for how we understand regulation in this area.

\section{More Stringent, or Simply Different?}

This article considers one element of this specific variation in the polluter pays principle, and that is the extent to which the owner or occupier of land who did not cause or permit the contamination may be liable for the costs of remediation of damage to land. The ELD imposes no such liability. The ELD does allow, however, for Member States to 'maintain or adopt more stringent provisions in relation to the prevention and remedying of environmental damage'. ${ }^{2}$ In the absence of a clear definition as to what constitutes 'more stringent' legislation, the Member States have tended, as the discussion below will demonstrate, to simply keep in place existing liability regimes for the remediation for contaminated land which impose liability beyond that which the ELD imposes. Such legislation is not, however, more stringent. It does not impose a higher burden for liability onto anyone, rather it represents a completely different approach to liability.

The strength of this argument is demonstrated by the reference to it by AG Kokott in Raffinerie Mediterranee (ERG) SpA v Ministero dello Sviluppo Economico (Raffinerie Mediterranee). ${ }^{3}$ She argues that:

The Commission takes the view that such liability is permissible as a more stringent measure under art.176 EC and art.16 of the Environmental Liability Directive. I cannot concur with that view unreservedly, however. Liability irrespective of any causal contribution would neither follow the policy of the Environmental Liability Directive nor be compatible with it if it diminished the liability of the person who is responsible for the environmental damage under the Directive. ${ }^{4}$

Thus, requiring a non-polluter to pay for environmental damage is not more, or less, strict. It is a different basis for liability and one which is inconsistent with the ELD's understanding of the polluter pays principle. Nevertheless, such divergence in Member State legislation is permitted. This has clear consequences for owners and occupiers of contaminated land since they are unable to rely on the harmonising effect of the ELD to delineate their liability. Furthermore, the ELD applies only to on-going pollution ${ }^{5}$ and given the breadth of the scope of the Directive itself in terms of the environmental damage tackled, ${ }^{6}$ it might be thought that it would control liability for on-going pollution, and restrict that liability to polluters with a direct causal connection to the relevant pollution. But this is not the case. According to the Union model of liability, such would be a breach of the polluter pays principle. The consequence of this is that Union ideal of harmonised internalisation of the costs of polluting cannot be achieved. Thus the difference in the national regimes is not a question or more or less stringent legislation: it represents diametrically opposed understandings of how the polluter pays principle works.

It is also necessary to highlight here that national measures, as in the UK, for example, apply to different kinds of land, and the definition of causation, or operator, etc. will vary from

\footnotetext{
${ }^{2}$ ELD, article 16.

${ }^{3}$ C-378/08 Raffinerie Mediterranee (ERG) SpA v Ministero dello Sviluppo Economico [2010] ECR I01919.

4 ibid, [AG97]-[AG98].

${ }^{5}$ ELD, articles 17 and 19.

${ }^{6}$ ELD, articles 2(1) and 3(1).
} 
Member State to Member State. Thus, the ELD definition of damage to land requires that the existence of a substance in, on, or under the land pose a threat to human health. This is not the case in the Environmental Protection Part, IIA, in the United Kindgom, where land is also considered to be contaminated if a threat is posed to property, for example (DEFRA, 2012, Table A).

Similarly, the definition of operator in the ELD, at article 6, states that:

"'operator' means any natural or legal, private or public person who operates or controls the occupational activity or, where this is provided for in national legislation, to whom decisive economic power over the technical functioning of such an activity has been delegated, including the holder of a permit or authorisation for such an activity or the person registering or notifying such an activity".

This definition is not one which, on its face, is purely causal. Rather, the link is direct cause, or indirect cause through control over an activity. Whatever the precise scope of this definition however, the justification for liability expressed in this definition is one of causation or control of the causing activity, not through the relationship with land. Indeed, as AG Kokott highights in Raffinerie Mediterranee, ${ }^{7}$ this may mean that an owner or occupier of land is found to be an operator due to his control over activity on that land, even if he does not carry out that activity himself. Nevertheless, his liability is a causal liability, since he is able to intervene in the chain of events culminating in the damage to the relevant land. This is fundamentally different from liability falling onto an owner or occupier of land solely by virtue of ownership rights in that land. Such variation is not about legislation being "more stringent". Such can be made clear if the simple question is asked: more stringent, for whom? The answer is that legislation which requires an owner to pay is more stringent for the owner, but less stringent for the polluter. This is not a matter of stringency at all, therefore, but a different approach to the relationship between cause, and liability.

\section{The Polluter Pays Principle}

Thus, there are two possible interpretations of the polluter pays principle as a justification for liability. The first is that the polluter pays principle demands that only the polluter pay for damage caused by their activities (OECD, 1972; Gaines, 1991, 468 and Stevens, 1994, 578). If anyone else can be made to pay, then the cost of polluting is not fully internalised. This accords best with the principle's foundation as an economic principle advancing free trade, (de Sadeleer, 2005, p. 34) in light of 'patchy' environmental protection legislation. The second way of understanding the principle is to divorce it from a purely economic understanding, and instead to rely on it as a principle expressing various considerations based in justice. It is 'fair' that the polluter should pay for damage they have caused (Lee, 2009, 267). Under such an approach it may also be 'fair' for another person to pay to remediate such damage, or indeed for the state to intervene. The first approach sees the principle as excluding liability for others: the second does not. These two interpretations of the principle are incompatible. A system based on one is fundamentally different (not more or less strict) than a system based on the other. Examination of the European contaminated land regimes reveals that both are present in a supposedly harmonised system.

Taking this analysis further, we can begin to build models of liability for remediating contaminated land, which demonstrate the variations in how such liability is justified. This article considers five such models. Only the first embraces the polluter pays principle as an exclusionary principle. Models two to five represent variations whereby any invocation of the polluter pays principle must be as just one amongst many possible justifications for the imposition of liability.

\section{Model 1}

\footnotetext{
${ }^{7}$ n 3 above, [AG107].
} 
The polluter should pay and no one else should pay. If the polluter cannot be found, there will be no liability for remediation.

\section{Model 2}

As a priority the polluter should pay, but where the polluter it may be possible for residual liability to rest elsewhere on e.g. owners or occupiers of land, or the State.

\section{Model 3}

As a priority the right sort of polluter should pay, but that if the polluter does not meet those criteria (e.g. fault), then others may also be liable. Causation is not the only test for being a polluter.

\section{Model 4}

Liability is based primarily upon fault, not causation.

\section{Model 5}

The polluter may be liable, but so equally may others be, regardless of fault.

Within these models lies some variation in definitions. For example, these rough models do not tell us whether the 'knowing permitter' is a 'causer' (as is arguably the case for the ELD itself), nor do they explain whether the purchaser who acquires land and ought to have realised such land was contaminated can be considered to be 'at fault'. The different understandings of the polluter pays principle that these models explain, do not, therefore, explain the precise conditions under which liability can be imposed for remediation. Nor, of course, do they engage with the meaning of damage. The definition of damage present in national law may very well too vary in ways not explored here. Notwithstanding variation in other elements of the Directive however, it is still important to understand the different ways in which the polluter pays principle is integrated into national law, and what the consequences of this are for the ensuing systems.

\section{Member States: Models for Liability}

Before considering the approach taken across the Member States in relation to the place of the polluter pays principle within liability for contaminated land, it is necessary first to explain the selection process. Firstly, the discussion excludes those countries which have simply directly transposed the ELD where the only liability, past or present, arises under the ELD. These Member States are Cyprus, Malta and Greece. Additionally, this article does not use as examples those countries where there can be no future liability under law other than the ELD. Such countries essentially impose a cut-off date after which only the ELD can apply. Similarly excluded from consideration are provisions (particularly prevalent in former-Soviet countries) whereby the State assumes liability for remediating contaminated land where such land became contaminated when State-owned, but which is now in private hands. Such provisions, although strictly allowing for the costs of pollution to burden someone other than a polluter (since causation by the State entity need not be proved), are a pragmatic response to a wholesale shift in the ownership of land. Furthermore, they represent a very limited incursion into the principle that the polluter ought to pay. Although the State assumes liability for historical contamination without the need to prove causation, it is based on the assumption that if such land is contaminated, the contamination occurred during the era of State ownership.

Thus, this article has considered regimes whereby the existing national law or new supplementary national law sits alongside the regime imposed by the ELD. The operation of such parallel regimes reveals the range of options for justified liability, and thus a range of justifications which call into question the Union interpretation of the polluter pays principle. In particular, it reveals the varying extents to which different Member States rely on the 
liability of an owner of land for remediating contaminated land. Such reliance is far from harmonised. As a result, the pan-European impact of a drive to ensure that the costs of pollution are internalised is patchy.

The following table summarises the results of this review. It is a necessary simplification of the regimes in place. In particular, it does not take account of civil liability for remediating contaminated land unless that is the only regime in place. Such civil liability tends to be fault based and depends upon causing damage to another. It is therefore different from liability to remediate one's own land, for example. The table also assumes that liability for owners/occupiers is fault based if knowledge or notice are required before an owner can be liable. The simple existence of an innocent purchaser defence does not however mean that owner liability is fault-based since a person who inherits land may too have no knowledge or notice of the contamination but will not be able to avail themselves of the protection of an innocent purchaser defence. This table reveals the range of models in place across the Member States. Specific examples from each group are discussed below after a more detailed discussed on the ELD itself.

[Insert Table One: Table of Regimes]

\subsection{The ELD}

The first model, as outlined above, is the model adopted by the ELD. As Larson discusses: 'the Commission argues, the polluter pays principle demands that the actor whose conduct is inherently dangerous to the environment bear the risk of damage caused by their conduct, rather than the victim of the damage or society at large' $(2005$, p. 559). Further evidence that the ELD is representative of this model is to be found in the wording of the Directive itself, and specifically paragraph 13 of the preamble:

Not all forms of environmental damage can be remedied by means of the liability mechanism. For the latter to be effective, there needs to be one or more identifiable polluter, the damage should be concrete and quantifiable, and a causal link should be established between the damage and the identified polluter(s). Liability is therefore not a suitable instrument for dealing with pollution of a widespread, diffuse character, where it is impossible to link the negative environmental effects with acts or failure to act of certain individual actors.

It stipulates, in essence, that in order to operate effectively as an economic principle, the polluter pays principle must mean that all the costs associated with pollution rest on the polluter. Otherwise, the costs are not internalised, and the impact of the principle is consequently limited. As AG Kokott states in Raffiniere Mediterranee: ${ }^{8}$

According to the 'polluter pays' principle, the person who caused pollution is responsible for remedying it. Language versions other than the German, which expressly state that the polluter should pay ('polluter pays' principle, principe du 'polleur-payeur'), make it clear that it is a principle governing liability for costs. It is not society or third parties, but the polluter who should pay the costs of eliminating pollution. Consequently, there is an internalisation of environmental costs.

None of the relevant regimes adopts this approach wholesale. All of the Member States which have existing or supplemental legislation interpret the polluter pays principle as allowing for even very limited liability to fall onto others (usually the State). Nevertheless, as can be seen from the table, some regimes come close. Under such regimes, '[t]he establishment of a

\footnotetext{
${ }^{8} \mathrm{n} 3$ above.

${ }^{9}$ ibid, [AG85].
} 
causal link between the activity and the damage is always required' (European Commission, 2014b). Thus causation, not fault, is the benchmark for liability, and in addition there is no liability that attaches to rights in land. This interpretation of the polluter pays principle by the institutions of the EU is further emphasised by the ECJ in Commune de Mesquer v Total France: "The application of the 'polluter pays' principle within the meaning of the second sentence of the first subparagraph of Article 174(2) EC and Article 15 of Directive 75/442 would be frustrated if such persons involved in causing waste escaped their financial obligations". ${ }^{10}$ This must include those cases where another person in addition or instead of the causer is required to meet the cost of remediation. Similarly, at [89]: "[i]n accordance with the 'polluter pays' principle, however, such a producer cannot be liable to bear that cost unless he has contributed by his conduct to the risk that the pollution caused by the shipwreck will occur". ${ }^{11}$ The Union institutions therefore interpret the polluter pays principle as relying on a causal link, and as on requiring a complete internationalisation of costs arising from such action.

Even the ELD however has made concessions to the possibility for liability for others, in a very limited way. Thus article 8(2) provides that member states may introduce regulations which allow for the state itself to meet some of the costs of remediation but where the cost of attempting to recover the remediation costs is higher than the sum which would be recovered. ${ }^{12}$ The Directive therefore makes a concession to administrative difficulties in recovering costs: it does not make a concession to the principle that liability should be based on causation alone. Similarly, article 8(4) introduces a fault element for liability for pollution caused where the emission itself was in accordance with a permit - essentially a 'best state of scientific knowledge' defence. Again, this is a concession to the limits of scientific knowledge. Neither as an economic principle, nor as a principle of justice, is it necessary to impose liability where the polluter could not have known that they were a polluter on the basis of the limits of scientific knowledge at the relevant time. These provisions are optional for the Member States, but they demonstrate that the ELD does conceive limits on the potential scope of causal liability. What they do not suggest is that the ELD recognises that someone other than the polluter should pay.

\subsection{Model One: Denmark}

The closest example to model one is the Danish system, and this system has only a very limited exception to the rule that the costs of pollution must be internalised. Other countries with a broadly model one system are the Czech Republic, Lithuania, Luxembourg and Slovenia. It should be noted from the outset that the Danish system involves two liability 'routes'. The first route is where environmental damage under the ELD exists. By this route, liability is causal on the basis of the Directive. Chapter 4a of the Contaminated Soil Act (CSA) effectively directly transposes the Directive for environmental damage. The second route applies where there is no "environmental damage" within the definition of the Directive (Chapter 5, CSA). It is this latter route that is considered here. It will thus be particularly important for historical contaminatiom occurring before the coming into force date of the ELD. There are not, therefore, two possible liability routes in Danish law: the ELD and the purely national law liability do not overlap. The Danish example however demonstrates well the operation of a national law system which sees causation as the only possible justification for liability, and the national and the EU law sit beside one another very comfortably, both being based on this causal approach.

Under Danish law, liability is imposed on the basis of causation (section 41, CSA). The owner of land is never liable for the costs of remediating contamination simply by virtue of

\footnotetext{
${ }^{10}$ C-188/07 Commune de Mesquer v Total France, [2008] ECR I-04501, [72].

${ }^{11}$ ibid, [89].

${ }^{12}$ ELD, article 8(2).
} 
their ownership rights (U1991.674H (Rocwool Sagen); Basse, 2000, p. 72). The only nod to the need to remediate land where the polluter cannot be found is in the establishment of a fund whereby the owner of a domestic property can apply to the state for funds to remediate contaminated land themselves (section 49, CSA; Bio Intelligence Service, 2013b, 35; Basse, 2013 , p. 224), or where, for land contaminated before 1992, the innocent owner of residential land applies to a remediating authority for their land to be cleaned (Chapter 4, CSA). In this later case, the authority may request a fixed sum contribution from the owner (section 31, CSA). In addition, where a notice is served in relation to land with an innocent owner, in a small class of cases, compensation will need to be paid as a result of constitutional protection against expropriation, (Basse, 2013, p. 79). Such owners of land are also able to claim compensation for any damage caused by remediation measures, (Basse, 2013, p. 224). Here, the State is assuming the cost of remediation, but only to a limited extent. The general principle is that causation of pollution is the only justification for liability to remediate the land damaged by such pollution. Thus, under the section 41(3), CSA the polluter is any person who carried out an activity from which contamination originates. Liability for contamination is, therefore, based on causation.

The Danish approach to remediation of contaminated land, as with the ELD, is therefore one which sees the value in the polluter pays principle as an exclusionary principle for liability (with the limited exception of state funds made available to non-causing homeowners). Furthermore, what is particularly clear from the Danish approach, and from the decision in U1991.674H (Rocwool Sagen), is that the model for liability does not allow for owners or occupiers to be saddled with the cost of remediation. If no polluter exists, it may in residential property be possible to rely on State action (where land was contaminated prior to 1992), but no individual who is not a polluter can be made liable. Thus there is a strong conception that liability for others undermines the polluter pays principle.

\subsection{Model Two: United Kingdom}

Such an approach is not however widely shared. More common in the Member States (as can be seen from the table above) is the approach represented by model two. The systems which have adopted a model two approach include Austria, Bulgaria, Estonia, Finland, France, Hungary, Romania, Slovakia, Spain, Sweden and the United Kingdom. This approach gives primary liability to causers of contamination under a strict liability model, but imposes secondary liability onto owners or occupiers (whether based on fault or not) if, for example, the polluter cannot be found or has insufficient funds to meet the cost of remediation. There are many variations on this model, with, for example, innocent purchaser defences limiting the scope of secondary liability or State liability making up part of the secondary liability. The variation in this model can be seen by reference to the above table - compare, for example, the Finnish and French systems.

For the purposes of comparison in philosophy however, the example of model two considered here is the contamination land provisions in the UK. The rules concerning contaminated land are contained in the Environmental Protection Act 1990 Part IIA (EPA 1990). The regime imposes primarily liability onto a person who 'caused' or 'knowingly permitted' a contaminating substance to be in, on or under land. ${ }^{13}$ The meaning of 'causing' and 'knowingly permitted' are not defined in the legislation, but interpretation from case law suggests a broad approach will be used ( $R$ (Crest Nicholson $v$ Secretary of State for the Environment) (Lochery 2010). ${ }^{14}$ Causal liability is therefore wide, and, except in so far as 'knowing permission' involves fault, is strict liability. Thus for the polluter himself, causal

\footnotetext{
${ }^{13}$ EPA 1990, section $78 \mathrm{~F}(3)$.

${ }^{14} R$ (On the application of Crest Nicholson Residential Ltd) v Secretary of State for Environment, Food and Rural Affairs [2010] EWHC 1561 (Admin) [2011] Env. L.R. 1. See also Walker and Son (Hauliers) Ltd v Environment Agency [2014] EWCA Crim 100; [2014] PTSR 929 (CA (Crim Div)).
} 
liability is imposed. However, if the polluter (Class A person) cannot be found, so-called 'Class B' persons may be liable. These are the owner or occupier of the land for the time being. ${ }^{15}$ This person is liable to remediate the land simply because of their legal rights in that land or, through their occupation and associated control, their physical presence on that land.

It is the existence of secondary liability which characterises this model for interpretation of the polluter pays principle. The liability is justified not by fault or causation, but by a direct relationship with the land. The guidance on the contaminated land provisions in the UK demonstrates that the primary objectives of the regime are not to ensure that the polluter who caused damage is made to pay for that damage, but rather than the damage is remediated:

The overarching objectives of the Government's policy on contaminated land and the Part 2A regime are: (a) To identify and remove unacceptable risks to human health and the environment. (b) To seek to ensure that contaminated land is made suitable for its current use' (DEFRA, 2012, [1.4].)

In this regime, unlike the ELD therefore, the polluter pays principle is a principle of liability, but it is not also the aim of the regime to impose liability onto a polluter to the exclusion of other potential liable persons. In this model therefore we can see a significant difference in the interpretation of the polluter pays principle when compared with the principle as explored through the ELD.

\subsection{Model Three: Walloon Region}

A further, but much less common, variation on the 'primary liability for a polluter' approach is the basis of model three, and again, this model is one which does not treat the polluter pays principle as a principle which excludes liability for others. Under such a system, although the polluter is primarily liable, this liability is not solely based on causation. There is a fault element in the liability criteria for the polluter. Such is a clear expression that the legislator believes the polluter pays principle to be an expression of a principle of justice, rather than an economic principle, since they have expanded upon the principle to include fault within the justification provided for the imposition of liability.

This can be seen in the system adopted by the Walloon Region in Belgium (the Belgian regions have control over contaminated land). The Décret Relatif à la Gestion des Sols (DRGS) has been in force since 2009 and mostly operational since January 2013. Under this system, primary liability for remediating contaminated land falls onto the polluter, as long as that person was at fault. ${ }^{16}$ If such a person cannot be found, liability will fall onto the operator of an activity subject to an environmental permit ${ }^{17}$ unless the operator cannot be found or has insufficient funds, in which case the owner of the land will then be liable. ${ }^{18}$ This owner of land can avoid liability if:

- The pollution results from migration of contaminants from other land

- A control certificate has been issued

- The appropriate public authority has issued a confirmation of the proper execution of remediation works

- Or the owner/ occupier etc was not negligent or at fault and the pollution did not appear to pose a threat at the time on the basis of scientific knowledge at the time at which it occurred. ${ }^{19}$

\footnotetext{
${ }^{15}$ EPA 1990, section 78F(4).

${ }^{16}$ DRGS, article 22(3)(b) and articles 23 and 24.

${ }^{17}$ DRGS, article 22(3).

${ }^{18}$ DRGS, article 22(4).

${ }^{19}$ DRGS, article 25. Author's own translation.
} 
Thus liability for the owner of the land is not fault based as such, but instead is tied directly to the rights they have in the land, subject to the state of scientific knowledge defence outlined above. Liability for a polluter is however fault based. The Walloon system recognises to a certain extent that the internalisation of the cost of pollution may only be justified where the causer of the pollution is aware or should be aware of the potential damage that may be caused by their activity. However, there is also an awareness of need to remediate land even where there is no such fault, and so the secondary liability of the holder of an environmental permit, and the tertiary liability of the owner, lessee, usufruct etc. allows for remediation in the absence of a faulty polluter.

\subsection{Model Four: Netherlands}

Reliance on fault as part of the standard for liability is therefore an element in the third model, but it is the driving force behind the fourth model for liability. This model is adopted by the Netherlands. ${ }^{20}$ It relies not on causation, but on fault as the primary justification for liability. The system is somewhat complex, with the liability dependent upon the date of contamination. Focusing on the 'current' law, the principle is that a person who 'knows or might reasonably have suspected' that their activity might cause contamination may be liable to the costs of remediating that land. ${ }^{21}$ The owner or lessee of the land may also be liable. ${ }^{22}$ The Netherlands system therefore has priority liability for the faulty causer, and secondary liability for the owner, but only where that owner too has an element of fault due to a legal relationship with the polluter, an involvement in the contaminating activity, or knowledge or notice of the contamination on purchase. ${ }^{23}$ Thus under the Netherlands system, liability is based primarily upon fault, not causation and indeed, the Soil Protection Act (Wet Bodembescherming) allows for recoupment of costs by the State against a responsible party on the basis of the principles of tort law, (article 74; Heldeweg and Seerden, 2013, p. 117), which requires not only causation, but also accountability (Heldeweg and Seerden, 2013, p. 204). This exists alongside the provisions enacting the ELD in Title 17.2 Environmental Management Act (Wet Milieubeheer) at article 17.16, section 1 whereby "a qualitative or risk-liability of the (causal) operator" (Heldeweg and Seerden, 2013, p. 202) is established.

This model of course represents quite a significant shift in the understanding of the polluter pays principle. It is significant that both the owner of land and the polluter are subject to this fault-based test, underlining the extent which liability is based on the assumption of some responsibility for the consequences of actions on land, rather than through the notion of a causal link. This model therefore relies on a very different understanding of the justifications for the imposition of liability than does the ELD. Whilst the ELD attempts to ensure that polluters take care by imposing liability on them whether or not they are at fault, thereby internalising the cost of pollution regardless of any assumption of responsibility (through faulty behaviour) by the polluter, the system in place in the Netherlands regards fault as central to liability.

\subsection{Model Five: Germany}

This principle of relying on factors other than causation as being drivers for liability is taken to its ultimate conclusion in the fifth model being considered here, whereby the polluter pays principle is seen as being simply a principle which justifies liability amongst many other possible justifications. The model is adopted in Germany, Ireland and Latvia, but for the

\footnotetext{
${ }^{20}$ The primary legislation is the Soil Protection Act (SPA) (Wet Bodembeschermi) which came into force in 1987.

${ }^{21}$ SPA, article 13.

${ }^{22}$ SPA, article 43.

${ }^{23}$ SPA, article 46.
} 
purposes of comparison the German system will be considered here. This approach asserts that no priority comes from being a polluter in terms of liability, but nor, unlike the Dutch system, does it allocate liability on the basis of causation or fault. It goes beyond this and imposes liability on the basis of causation, or fault, or by a legal relationship with the relevant land.

The primary German regulation relating to contaminated land applies where the activity causing the contamination has ceased. It relates primarily therefore to historical contamination. Where contamination has occurred there are many persons who may be liable to remediate the land. These include: the polluter, the legal successor to the polluter; the owner; the tenant or other occupier; the former owner unless that owner did not know of the contamination when it acquired the land (providing such a lack of knowledge was reasonable). ${ }^{24}$ All these persons are jointly and severally liable, although the amount of remediation cost to which a person may be held liable is limited by the requirements of the proportionality principle. ${ }^{25}$ This principle, as interpreted by the German courts, means that the owner of land is unlikely to be liable for costs exceeding the value of the land unless the acquired the land with knowledge of contamination (Decision of the Federal Constitutional Court, BB 2000, at 1369). Thus the scale of costs liability may vary according to fault etc., but the existence of liability is based on a wide range of justifications. The owner of land will however be required to pay some cost where the clean-up of the residual pollution on his land has resulted in an increase in the value of his land (section 25(6), Federal Soil Protection Act of 17 March 1998; Schlemminger and Martens, 2004, p.156).

\section{Consequences}

This survey of the different mechanisms for liability for contaminated land across the Union, and the explanation of the different models adopted by different Member States, has demonstrated a significant degree of variation in approach to remediation of contaminated land. This has two important consequences. It firstly has consequences for the shape of the polluter pays principle as a principle across the Union, and thus for the interpretation of this principle by the Courts. The second consequence, more practical in effect, is for the position of owners and occupiers in relation to contaminated land. Before considering these consequences in more detail however, it must firstly be clarified that it is entirely possible that the Member States in question are not trying to implement the polluter pays principle with their national legislation. Indeed, it is not even argued that such legislation is adopted on the basis of that principle. However, by implementing the ELD alongside such legislation, the Member State is necessarily adopting an interpretation of the polluter pays principle which diverges from that of the ELD since the ELD demands that only the polluter pay. Thus, even where legislation is not based on that principle, the very existence of the divergence is in itself a threat to the coherence of the interpretation of the principle within the ELD across the Member States.

Thus, in terms of the interpretation of the polluter pays principle, the variation in the understanding of this principle will have important consequences for the harmonised interpretation of the ELD. The ELD is explicitly based on the polluter pays principle. The ECJ in Raffinerie Mediterranee highlights the importance of this principle as part of the Union environmental law, and the critical need to ensure that causal links are the only justification for liability to remediation pollution.

Directive 2004/35 does not preclude national legislation which allows the competent authority acting within the framework of the directive to operate on the presumption, also in cases involving diffuse pollution, that there is a causal link between operators

\footnotetext{
${ }^{24}$ Federal Soil Protection Act of 17 march 1998, article 4.

${ }^{25}$ Decision of the Federal Court, 1 BvR 242/91 and 315/99 (16 February 2000).
} 
and the pollution found on account of the fact that the operators' installations are located close to the polluted area. However, in accordance with the "polluter pays" principle, in order for such a causal link thus to be presumed, that authority must have plausible evidence capable of justifying its presumption, such as the fact that the operator's installation is located close to the pollution found and that there is a correlation between the pollutants identified and the substances used by the operator in connection with his activities. ${ }^{26}$

Thus, although national law can introduce presumptions to help with the proof of causation, there is still a very clear need, in order to correctly implement the polluter pays principle, to ensure that a causal link exists. As AG Kokott states in the same case: '[i]t is therefore correct to regard the causation of damage by an occupational activity as the primary requirement for liability for environmental damage under the Directive'. ${ }^{27}$ Any legislation which does not see this as being the threshold for liability is at odds, conceptually, with the Directive.

Although primary responsibility for the interpretation of Union law vests with the ECJ however ${ }^{28}$ national courts too are required to interpret national law transposing Union law and Union law itself, and are therefore too tasked with the role of unpacking meaning from the ELD by reference to the polluter pays principle. By taking such a range of understandings of the polluter pays principle however, it is clear that interpretation based on this principle is likely to vary across the Union. Primarily, this means that in those States where the polluter pays principle is understood not as an exclusionary principle for liability, but rather as one amongst other possible justifications for liability, the systems which develop will not be more or less strict than each other, they will be fundamentally different.

What this shows is that without a harmonised understanding of what role the polluter pays principle plays as a justification for liability, any legislation that is based on, or required to work with, such a principle, runs into a problem. Some consequences of this are purely practical. Firstly, it means that where the transposing legislation does not make clear priority for remediation, there will often be a conflict between existing legislation based on a different model for polluter pays in relation to contaminated land; and secondly it means that the owner or occupier of land cannot rely on a harmonious system to articulate to them the standards that rest on them as owner/occupier with regards to liability for contamination. This will impact not only upon existing owners, but will impact too upon investment decisions, discouraging free movement of such investment throughout the Union (Layard, 2004, p. 99; Hollins and Percy, 1998, p. 126). This undermines the purpose of the ELD, and it also poses significant problems of uncertainty stemming from the uneasy interaction between national law models for contaminated land liability.

However, the consequences can go beyond merely practical difficulties in interpretation. This lack of harmony in terms of the principle itself produces a situation where although the principle is a principle of the Union itself, it is little understood and is relied on in various places to mean various different things. Confusion, and obfuscation abound from such lack of clarity in terms of the meaning of the principle. The potential for confusion can be seen clearly if the approach of AG Kokott in Raffinerie Mediterranee (the nuance in which warrants the lengthy citation here) is contrasted with the approach of the Court itself. Per AG Kokott:

It is not possible to derive from the 'polluter pays' principle an absolute prohibition on imposing the costs of remedying environmental damage on parties other than the polluters. Such a prohibition would be tantamount to accepting environmental

\footnotetext{
${ }^{26}$ n 3 above, [70].

27 ibid, [AG82].

${ }^{28}$ C-106/77 Amministrazione delle Finanze dello Stato v Simmenthal SpA [1978] ECR 00629.
} 
damage where the polluter cannot be made liable. Even where remedial action is taken at public expense, the costs have to be borne by someone who is not responsible for the damage. However, accepting environmental damage would be incompatible with the aim of encouraging a high level of environmental protection and improving the quality of the environment. The function of "polluter pays" principle is to help to achieve that objective, which is laid down not only in art.174(2) EC, but also in art.174(1) EC, and above all in art.2 EC . The "polluter pays" principle may not be construed in such a way that it is inconsistent with environmental protection, for example by preventing the remedying of environmental damage where the liability of the person responsible cannot be established.

Accordingly, the Environmental Liability Directive also accepts that remediation costs have to be borne by persons other than the operator responsible. In particular, it permits the State to take measures at its own expense if the polluter cannot be identified or is not capable of paying for the damage.

If a polluter cannot be identified, the fair apportionment of costs would justify requiring the owner of the cleaned up land to bear the remediation costs since the value of that land is increased. Otherwise, he would be unreasonably enriched at the expense of others. ${ }^{29}$

Her approach, in effect, is that polluter pays principle justifies liability. It does not exclude liability. The Court itself, by contrast, states simply that: 'the competent authority is required to establish, in accordance with national rules on evidence, a causal link between the activities of the operators at whom the remedial measures are directed and the pollution' ${ }^{30}$ These two approaches, fundamentally opposed, cannot sit side-by-side in one system based on this principle. The failure to clearly delineate which model of the principle has been adopted produces a fundamental weakness in the ELD harmonisation scheme.

\section{Justifying Liability for Land Damage}

Thus, the variation in itself is likely to prove problematic from a practical perspective, and indeed, from a conceptual perspective. Of course there is a balance to be struck, but when a survey of the Member States is carried out, as here, it becomes apparent that in many regimes, environmental protection is advanced by engaging land-owners with the process of remediation. Total reliance on the polluter pays principle as an exclusionary principle for liability may in fact undermine environmental protection where such reliance is not practically possible. The inability of polluters to pay does not need to be a barrier to remediation where the polluter pays principle is simply seen as a justification for liability. It is however a barrier where neither the State nor the owner or occupier of the land is liable. Reliance on the owner or occupier of land is therefore warranted, either as primary or secondary liability, if, for example, the justice in the principle of stewardship is considered. By relying on the polluter pays principle entirely in the drafting of the ELD, the Union approach overlooks this.

It is notable moreover that in those Member States where model one or something akin to model one is adopted, the holder of rights in land may, under certain circumstances, obtain a windfall due to the rise in the value of their land following remediation, a windfall for which they have to take on board no responsibility (Lees, 2015). Furthermore, any notion of stewardship and of the need to ensure that land is in a good state for the benefit of current or future users of that land is delegated entirely to current and past users of the land (Lees, 2012). Those with rights in the land itself, and thus overall control of that land, are not tasked

\footnotetext{
${ }^{29} \mathrm{n} 3$ above, [AG112] - [AG114].

${ }^{30}$ ibid, [order].
} 
with a similar role. This seems to underplay the strengths of the justifications for liability to keep land in 'good repair', even where the state of disrepair was not caused by the current owner. Thus, the model one approach is one which neglects to fully engage with the justifications which may exist for liability beyond liability in causation (and thus in the concept of internalisation of polluting costs). This is where the remaining divergence within models two to five becomes particularly noteworthy. Each points not only to a divergence in terms of the polluter pays principle, but more fundamentally, to further divergences in terms of environmental justice. Fault, causation, ownership rights, and State involvement are all considered, in different places, to justify liability. This means that for those who see the environmental principles as a framework around which to "rally", and as a basis upon which a coherent environmental law can be built, a problem emerges. The principles, as things stand, simply cannot encapsulate all that is required in terms of environmental justice. Any attempt to simplify liability justifications to questions of polluter pays, for example, is left not only with divergent interpretations of that principle, but of divergent interpretations of the counterjustifications. In order to harmonise, but also to rationalise, our understanding of justified liability for land damage within the EU therefore, not only do we need to work out a 'better' definition of operate, of land damage, and of cause in a precautionary world, but also to consider, more openly, why we are imposing liability in the first place. Only then will it be possible to understand what the polluter pays principle means, and therefore to utilise that principle as a fixed point within the legal system.

\section{Conclusion}

Thus we can draw three crucial conclusions from this review of the approach to the polluter pays principle, and to liability for owners and occupiers, throughout the Member States. Firstly, although the ELD itself allows for the maintenance of stricter national legislation relating to the remediation of environmental damage, without any definition of 'more stringent', it is not clear that the national law in place can really be described as more or less stringent. Rather, being based upon fundamentally opposed understandings of the polluter pays principle, the systems throughout the Union are profoundly different. Secondly, such difference arises because of different interpretations of a single principle of European law. This has important consequences for the consistency of interpretation of this principle throughout the Union. Not only is there a lack of harmonisation in relation to the particular specific provisions for remediating environmental damage, there is also, to a surprising degree, a lack of harmony as to how the principle of polluter pays translates into a legal principle forming the basis of a liability regime. This has important consequences for owners or occupiers of land for whom their liability depends not on the harmonising provisions of the ELD, which, according to the ECJ demands that they not be liable unless a causal link can be proved, but on the state of their national law. The interaction between national law and Union law in this respect has been fudged, and as has been made clear in the report for the DG of the Environment, very often the relationship is simply not discussed in national law or guidance. Finally, this clash, which produces and is the product of incoherence in our approach to justifications for environmental liability, calls into question the supposed role of the environmental principles as points around which environmental regimes can congregate. Before coherence can be achieved therefore, more profound questions must be answered: who is the polluter, what do we want a polluter to pay for, and, as this article has shown, is it only the polluter who must pay?

\section{References}

- Basse, E. M., (2013), Environmental Law in Denmark. Alphen aan den Rijn, Kluwer Law International.

- Bergkamp, L. and van Bergeijk, A., (2013), 'The ELD's National Transposition' in Bergkamp, L. and Goldsmith, B. J., The EU Environmental Liability Directive. Oxford, Oxford University Press, pp. 139159. 
- $\quad$ BIO Intelligence Service (2013a), 'Implementation challenges and obstacles of the Environmental Liability Directive, Final report prepared for European Commission’ DG Environment, in collaboration with Stevens \& Bolton LLP.

- BIO Intelligence Service (2013b), 'Implementation challenges and obstacles of the Environmental Liability Directive, Annex -Part A: Legal analysis of the national transposing legislation prepared for European Commission' DG Environment, in collaboration with Stevens \& Bolton LLP.

- DEFRA (2012), 'Environmental Protection Act 1990: Part 2A - Contaminated Land: Statutory Guidance' DEFRA, London.

- $\quad$ de Sadeleer, N., (2005), Environmental Principles - From Political Slogans to Legal Rules. Oxford, Oxford University Press.

- $\quad$ de Sadeleer, N., (2006), 'Polluter-Pays, Precautionary Principles and Liability' in G. Betlem and E. Brans, Enviornmental Liability in the EU: the 2004 Directive Compared with US and Member State Law. London, Cameron May, pp. 89-101.

- $\quad$ de Smedt, K., (2009), 'Is harmonisation always effective? The implementation of the Environmental Liability Directive' European Energy and Environmental Law Review, pp. 2-18.

- European Commission 2006, 'Environmental Liability Directive: A Short Overview', http://ec.europa.eu/environment/legal/liability/pdf/Summary\%20ELD.pdf $\quad$ (accessed $2^{\text {nd }}$ November 2014).

- European Commission 2014a, 'Environmental Liability - Commission Report 2014' http://ec.europa.eu/environment/legal/liability/index.htm (accessed 2nd November 2014).

- European Commission 2014b, 'Environmental Liability Directive' http://ec.europa.eu/environment/legal/liability/ (accessed $2^{\text {nd }}$ November 2014).

- $\quad$ Gaines, S. E., (1991), 'The polluter pays principle: from economic equity to environmental ethos' Texas International Law Journal, Vol. 26, pp. 463-496.

- Heldeweg, M. A., and Seerden, R. J. G. H., (2013), Environmental Law in the Netherlands. Alphen aan den Rijn, Kluwer Law International.

- Hollins, M. and Percy, S., (1998) 'Environmental Liability for Contaminated Land - Toward a European Consensus’ Land Use Policy, Vol. 15, pp. 119-133.

- $\quad$ Layard A., (2004), 'The Europeanisation of Contaminated Land' Environmental Law Review, Vol. 6, 97-110.

- $\quad$ Lochery E., (2010), 'Causing Contamination' Scottish Planning and Environmental Law, Vol. 140, pp. 90-91.

- Lee, M., (2009), "New" environmental liabilities: the purpose and scope of the contaminated land regime and the Environmental Liability Directive' Environmental Law Review, Vol. 11, pp. 264

- Lees, E., (2012), 'Interpreting the contaminated land regime: should the "polluter" pay?' Environmental Law Review, Vol 14, pp. 98-110.

- $\quad$ Lees, E., (2015), 'Remediation of contaminated land: the polluter pays principle and stewardship' in Martin, p., et al, Towards a Jurisprudence of Implementation, Edward Elgar, Cheltenham, forthcoming.

- Organization for Economic Cooperation and Development (OECD), (1972), 'Guiding Principles Concerning International Economic Aspects of Environmental Policies, annex, Doc. C(72)128' (May 26, 1972).

- $\quad$ Schlemminger, H. and Martens, C-P., (2004), German Enviornmental Law for Practitioners $2^{\text {nd }}$ Edition. Alphen aan den Rijn, Kluwer Law International.

- $\quad$ Stevens, C., (1994), 'Interpreting the Polluter Pays Principle in the Trade and Economic Context' Cornell International Law Journal Vol. 27, 577-590.

- $\quad$ Stevens \& Bolton LLP, (2013), 'The Study on Analysis of integrating the ELD into 11 national legal frameworks, Final Report prepared for the European Commission’ DG Environment.

- Waite, A., (2006), 'The Quest for Enviornmental Law Equilibrium' in G. Betlem and E. Brans, Enviornmental Liability in the EU: the 2004 Directive Compared with US and Member State Law. London, Cameron May, pp. 49-87. 